\title{
DEVELOPING THE QUALITY OF ISLAMIC CORPORATE CULTURE ON ISLAMIC BANK IN INDONESIA
}

\author{
Muhammad Iqbal Fasa \\ Islamic State University Sunan Kalijaga of Yogyakarta \\ e-mail: muhammadiqbalfasa@ymail.com
}

\begin{abstract}
Financial institutions and contemporary business today have been transformed into a sharia-based financial institution and business. However, this change of a new transformation is done systemically by system and not implemented by culture. Thus, despite the growth of Islamic bank is so high, polemics is increasingly unsettled. Based on this, the necessary of transformation of corporate culture has to change based on Islamic values to create sustainable development and competitive advantage. This paper attempts to offer relevant ideas based on Islamic corporate culture. At the end of this paper, the author offers the characteristics of Islamic corporate culture, corporate culture in Islamic bank in Indonesia, and the development of quality of Islamic corporate culture on Islamic bank in Indonesia. This paper concludes that Islamic corporate culture has a major role in increasing employee motivation, employee work ethic, job satisfaction, employee's prestigious behavior and employee performance. Thus, it is important for Islamic banks to develop the quality of corporate culture based on Islamic values.
\end{abstract}

\section{Keywords: Islamic Corporate Culture, Islamic Bank, Sustainable Development}

\section{Introduction}

The occurrence of globalization and economic recession late 1990s led to the company radically forced to change its strategy and operations of the business. ${ }^{1}$ Changes in technology, market information systems, global economy, social values, workforce demographics, and political environment have a significant impact on processes, products and services produced. ${ }^{2}$ Changes in business processes can affect the performance of the organization, customer satisfaction and financial performance. $^{3}$

Lack of skills to adapt the management of the changes will lead to missed opportunities, career stagnation, selfdemotivation, implementation and poor quality. The results are delayed, additional costs, as well as the marginalization of the organization. ${ }^{4}$ Among other reasons of failure: failure of leadership transformation; do not appreciate the importance of external changes so quickly, and the failure of managers to pay attention to employee engagement. ${ }^{5}$

\footnotetext{
${ }^{1}$ Markku Kuula, et.al, "Effect of Change: A Longitudinal Study into the Changing Manufacturing Structures", Benchmarking: An International Journal, Vol. 21, No. 3 (2014), 329-343.

${ }^{2}$ Kamugisha Samuel, "The Effect Of Change Management In An Organization, Wyno Journal of Management \& Business Studies, Vol. 1, No. 1 (2013), 1-18. See also, John Edmonds, "Managing Successful Change", Industrial and Commercial Training, Vol. 43, No. 6 (2011), 349-353.

${ }^{3}$ Ivan Peronja, "Performance Effects of the Business Process Change in Large Enterprises", Management, Vol. 20, No. 1 (2015), 1-22.

4 Sanjiv Kumar, et al., "Change Management Skills: Leadership and Strategic Management for Health Professionals", Indian Journal of Community Medicine, Vol. 40, No. 2 (2015), 85-89.

${ }^{5}$ Xiongwei Song, "Why Do Change Management Strategies Fail"? Journal of Cambridge Studies, Vol. 4. No. 1 (2009), 6-15. See also, Michael Stanleigh, "Effecting Successful Change Management Initiatives", Industrial
} 
Failure indicates that the traditional model does not provide answer to the problems encountered. ${ }^{6}$

The most significant challenges when implementing change projects are: changing the mindset and attitude, underestimate the complexity, lack of resources, lack of commitment to a manager higher, lack of knowledge about the changes, lack of transparency, motivation of employees, process changes, changes in IT systems, technological barriers, ${ }^{7}$ and changes in organizational culture.

Changes made to the organization have a significant impact on the company's economic performance in long term. Research related to changing the organizational culture is a contemporary issue that develops massively. Research conducted by Gomez, et.al ${ }^{8}$; Alnasseri et.al $;{ }^{9}$ Naserinajafabady et.al; ${ }^{10}$ Danish et.al; ${ }^{11}$ Tojari, et.al; ${ }^{12}$, Yilmaz and Ergun; ${ }^{13}$ shows that there is positive and significant correlation between organizational culture and effectiveness of the company.

As the times progressed, the discussion of "organizational culture" is more specific into discussions relating to the approaches to ethics and values of Islam. Haque, et al is the first author to develop a model of organizational culture within an Islamic perspective. Some dimensions are offered, among others justice, honesty, hard work, sacrifice, accountability, mutual respect, cooperation, trust in God, missionary spirit, and sincerity. ${ }^{14}$ Based on this, this paper will discuss more in depth related to Developing the Quality of Islamic Corporate Culture on Islamic Bank in Indonesia.

\section{Organizational Culture: Theoretical Overview}

Organizational culture is a unity between "values", "belief" and "standard" that affects the mind and behavior of people in the company. ${ }^{15}$ Guiso, et.al, stated that organizational

and Commercial Training, Vol. 40, No. 1 (2008), 34 -37.

${ }^{6}$ Eddie Kikelly, "Creating Leaders for Successful Change Management", Strategic Human Resource Review, Vol. 13, No. 3 (2014), 127-129.

${ }^{7}$ Hans Henrik Jørgensen, et.al, "Stop Improvising Change Management”, Strategy \& Leadership, Vol. 37, No. 2 (2009), 38-44. See also, Phaik Lan Goh, "The Implementation Of Total Quality Management In Small and Medium Entreprise" (Disertation--University of Sheffield, 2010), 5.

${ }^{8}$ M. Elena Gómez-Miranda, dkk, "The Impact of Organizational Culture on Competitiveness, Effectiveness and Efficiency in Spanish-Moroccan International Joint Ventures", Personnel Review, Vol. 44, No. 3 (2015), 364387.

${ }^{9}$ Alnasseri dkk, "Organizational Culture, Leadership Style and Effectiveness: A Case Study of Middle Eastern Construction", Proceedings 29th Annual ARCOM Conference, England (2013), 393-403.

${ }^{10}$ Razieh Naserinajafabady, et.al, "Effects of Organizational Culture, Structure and Strategy on Organizational Effectiveness by Using Knowledge Management, Case Study: Seven International Transportation Company", International Research Journal of Applied and Basic Sciences, Vol, 7, No. 6 (2013), 355-361.

${ }^{11}$ Rizwan Qaiser Danish, et.al, "Moderating Role of Organizational Culture Between Knowledge Management and Organizational Effectiveness in Service Sector", World Applied Sciences Journal, Vol. 20, No. 1 (2012), 4553.

12 Farshad Tojari, et.al, "Structural Equation Modeling Analysis of Effects of Leadership Styles and Organizational Culture on Effectiveness In Sport Organizations", African Journal of Business Management, Vol. 5, No. 21 (2011), 8634-8641.

${ }^{13}$ Cengiz Yilmaz dan Ercan Ergun, "Organizational Culture and Firm Effectiveness: An Examination of Relative Effects of Culture Traits and The Balanced Culture Hypothesis in An Emerging Economy", Journal of World Business, Vol. 43, No. 3 (2008), 290-306.

${ }^{14}$ Nazamul Hoque, et.al, "Organisational Culture: Features And Framework From Islamic Perspective”, Journal Humanomics, Vol. 29, No. 3 (2013), 202-219.

15 Jernej Belak, "Organizational Culture in Relation to Enterprise Life Cycle", Kybernetes, Vol. 45, No. 4 (2016), 680-698. 
culture can be formed as a result of the creation of integrity among managers and employees. ${ }^{16}$

Organizational culture includes the mindset, feelings, and reactions that guide decisionmaking and other activities of the members of the organization. Successful organizations have a strong work culture so as to attract, keep and reward for anyone who meet obligations and achieve the target. ${ }^{17}$ Robbins presents seven characteristics of organizational culture: innovation and risk-taking, attention to detail, outcome orientation, people orientation, team orientation, aggressiveness, and stability. ${ }^{18}$

Specifically, the culture has five roles. First, culture provides a sense of identity and pride for the employees, which is to create a clear distinction between organizations with another. Second, the culture facilitates the formation of a culture of commitment and thinking broader than one's own interests. Third, it strengthens the organization's standards of behavior in the build superior customer service. Fourth, it creates a culture of adaptation patterns. Fifth, the culture builds control systems throughout the organization. ${ }^{19}$ The culture of the organization will have an impact on improving the quality of employees $;{ }^{20}$ organizational performance, ${ }^{21}$ and increase customer satisfaction. ${ }^{22}$

\section{Islamic Organizational Culture: Conceptual Framework}

Islam as a religion and a source of ethics has donated various concepts regarding various aspects of life, including in the organization. An organizational culture which is the implementation of the values embraced by the people of an organization can also be constructed using the values of Islam. Just as the concept of sincere, trustworthy, and the congregation. They are derived from the teachings of Islam. But not many organizations in the country use it. In fact, some of these values have been practiced by organizations outside of Islam. ${ }^{23}$

Organizational culture is built with a set of common values that all behavior in organizations. Islam as a source of values also has values that can be used as building a strong organizational culture. The values in the organization is also required to bind the manager and everyone in the organization to a unified whole. ${ }^{24}$ According to Hakim, the Islamic organization's culture is a value that is taken and developed to be applied in everyday life or

\footnotetext{
${ }^{16}$ Luigi Guiso, et.al, "The Value Of Corporate Culture", Journal of Financial Economics, Vol. 117 (2015), 6076.

${ }^{17}$ Lukman Hakim, "Budaya Organisasi Islamimi Sebagai Upaya Meningkatkan Kinerja”, Iqtishadia, Vol. 9, No. 1 (2016), 179-200.

${ }^{18}$ Nawawi Ismail Uha, Budaya Organisasi Kepemimpinan dan Kinerja: Proses Terbentuk, Tumbuh Kembang, Dinamika, dan Kinerja Organisasi, cet. ke-2 (Jakarta: Prenamedia Group, 2015), 8.

${ }^{19}$ Poerwanto, Budaya Perusahaan (Yogyakarta: Pustaka Pelajar, 2008), 26.

${ }^{20}$ Rama Krishna Gupta Potnuru and Chandan Kumar Sahoo, "HRD Interventions, Employee Competencies and Organizational Effectiveness: An Empirical Study", European Journal of Training and Development, Vol. 40, No. 5 (2016), 1-28.

${ }^{21}$ Sylvie Laforet, "Effects of Organisational Culture on Organisational Innovation Performance in Family Firms", Journal of Small Business and Enterprise Development, Vol. 23, No. 2 (2016), 379-407.

22 Miroslava Triznova, dkk, "CRM Based on Employees and Corporate Culture", Procedia Economics and Finance, Vol. 26 (2015), 953-959.

${ }^{23}$ Muhammad Husni, "Membangun Budaya Organisasi dalam Perspektif Nilai-Nilai Islam", Cendekia: Jurnal Hasil Penelitian dan Pengembangan Pendidikan Islam, Vol. 8, No. 2 (2015), 97-115.

${ }^{24}$ Ibid.
} 
activity using Islamic values in accordance with the guidelines of Islam, namely the Quran and Hadith. ${ }^{25}$

According Kusumawati, an Islamic organization culture values, thoughts and symbols based on Islamic norms that influence behavior, attitudes, and habits of a person's faith in some areas of life. ${ }^{26}$ Islamic organizational culture will lead to an Islamic perspective within the culture in order to provide a basis that can make the forms and ways that need to be organized collectively through an organization, making a call or invitation to a person (leader) to follow the teachings and rules. ${ }^{27}$ As word of Allah:

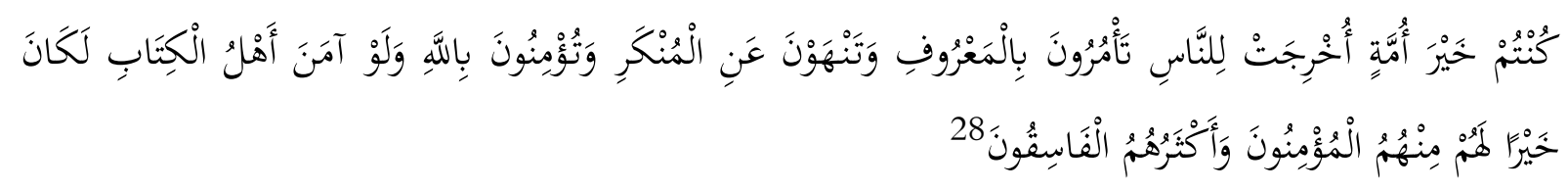

"You are the best community that hath been raised up for mankind. Ye enjoin right conduct and forbid indecency; and ye believe in Allah. And if the People of the Scripture had believed, it had been better for them. Some of them are believers; but most of them are evil-livers".

\section{Characteristics of Islamic Organizational Culture}

Hakim is the first writer in Indonesia, which suggests some characteristics of Islamic corporate culture. He departs from the epistemological concepts of Islamic economics, such as: ${ }^{29}$

1. Work is one implementation of human functioning as caliph.

2. Work is worship.

3. Working with the principles of benefit and interests.

4. Working with optimizing the intellect.

5. Work with confidence and optimistic.

6. Working with an attitude requires tawäzun (the balance).

7. Working with the attention element and avoid halal haram element.

Unlike the previous writer, this paper will offer the characteristics of Islamic corporate culture that departs from the value of the epistemological value of management and business concepts in Islam to internalize the values of Islam on the characteristics of conventional organizational culture. The seven characteristics of the culture of the organization are innovation and risk-taking, attention to detail, outcome orientation, people orientation, team orientation, aggressiveness, and stability. ${ }^{30}$

\footnotetext{
${ }^{25}$ Abdul Hakim, The Implementation of Islamic Leadership, 77-90.

26 Diah Ayu Kusumawati, "Peningkatan Perilaku Kerja Islami dengan Budaya Organisasi Islami sebagai Variabel Moderasi", $2^{\text {nd }}$ Conference In Business, Accounting, and Management, Vol. 2, No. 1 (2015), 233-242.

${ }^{27}$ Rezy Aziz and Atina Shofawati, "Pengaruh Kepemimpinan Islami dan Budaya Organisasi Islami terhadap Motivasi Kerja Islami pada UMKM Kulit di Magetan, Jurnal Ekonomi Syariah Teori Dan Terapan, Vol. 1, No. 6 (Juni, 2014), 393-409.

28 al-Quran, 3: 110.

${ }^{29}$ Lukman Hakim, "Budaya Organisasi Islami”, 179-200.

${ }^{30}$ Nawawi Ismail Uha, Budaya Organisasi Kepemimpinan, 8.
} 
Standardization of Islamic values in business, according to the Rival, is conducting business transactions according to the corridors of sharia. Second, not conducting business in a manner such falsehood maysīr, gharār, ribā, zulm, fraud, murder. Third, the purpose of a charitable act is not only oriented to the material (qïmah mädiyah), human values (qimah insāniyah), moral values (qïmah khuluqiyah), and the value rühiyah (qïmah rühiyah). ${ }^{31}$

Enforcement of Islamic business standards will be established to gradually characteristics company culture based on Islamic values, such as innovation continues to grow and the introduction of profit and loss sharing, attention in the details as sharia corridor, oriented to halāl results, maslahah maximization, and the creation of a balance of advantages and hereafter (faläh); human orientation as caliph in the world, team orientation based on siddiq, trust, sermons, fatänah and the principle of friendship; aggressiveness is not valuefree, and pay attention to the social aspects (zakat, donation, charity, endowments); stability in terms of fulfillment of maqāsid sharia, and the creation of a barakah.

Based on the explanation in a variety of sources in the preceding discussion, it can be a comparison of the characteristics of organizational culture in general with Islamic organizational culture as follows:

Table

Characteristics, Culture Organization, Culture Organization of the Islamic

\begin{tabular}{|c|c|c|}
\hline CHARACTERISTICS & $\begin{array}{c}\text { CULTURE } \\
\text { ORGANIZATION }\end{array}$ & $\begin{array}{l}\text { CULTURE ORGANIZATION } \\
\text { OF THE ISLAMIC }\end{array}$ \\
\hline $\begin{array}{l}\text { Innovation and courage to } \\
\text { take risks }\end{array}$ & $\begin{array}{l}\text { Innovation continues to grow } \\
\text { The risk is borne by one party }\end{array}$ & $\begin{array}{l}\text { Innovation continues to grow } \\
\text { Enforcement of profit and loss } \\
\text { sharing }\end{array}$ \\
\hline Attention to detail & According to SOP Company & According to the rules of sharia \\
\hline Result oriented & $\begin{array}{l}\text { Target oriented } \\
\text { maximization of profit } \\
\text { The pursuit of worldly gain }\end{array}$ & $\begin{array}{l}\text { halal oriented } \\
\text { Maximization maslahah, } \\
\text { Creation of a balance between } \\
\text { this world and the hereafter } \\
\text { (faläh) }\end{array}$ \\
\hline Oriented to humans & Humans as homo economics & Humans as a caliph in the world \\
\hline team oriented & $\begin{array}{l}\text { Teamwork } \\
\text { The relationship between } \\
\text { subordinates and superiors }\end{array}$ & $\begin{array}{l}\text { Siddiq berasas teamwork, trust, } \\
\text { sermons, fatānah } \\
\text { The relationship between } \\
\text { subordinates and superiors with } \\
\text { the principles of friendship }\end{array}$ \\
\hline Aggressive & $\begin{array}{l}\text { Free aggressiveness value } \\
\text { CSR is a company's social belle }\end{array}$ & $\begin{array}{l}\text { Aggressiveness is not value-free } \\
\text { Noting the social aspect in the } \\
\text { form of charity, donation, } \\
\text { charity, waqf (ZISWAF) }\end{array}$ \\
\hline
\end{tabular}

${ }^{31}$ Veitzal Rivai, dkk, Islamic Business And Economics Ethics: Mengacu pada Al-Qur'an dan Mengikuti Jejak Rasulullah SAW dalam Berbisnis, Keuangan, dan Ekonomi (Jakarta: Bumi Aksara, 2012$), 187$. 


\begin{tabular}{|l|l|l|}
\hline Stability & Good Cash Flow & $\begin{array}{l}\text { Maqāsid fulfillment of Sharia } \\
\text { creation of Barakah }\end{array}$ \\
\hline
\end{tabular}

In all the above discussion, it can offer a conceptual framework of Islamic organizational culture characteristics as follows:
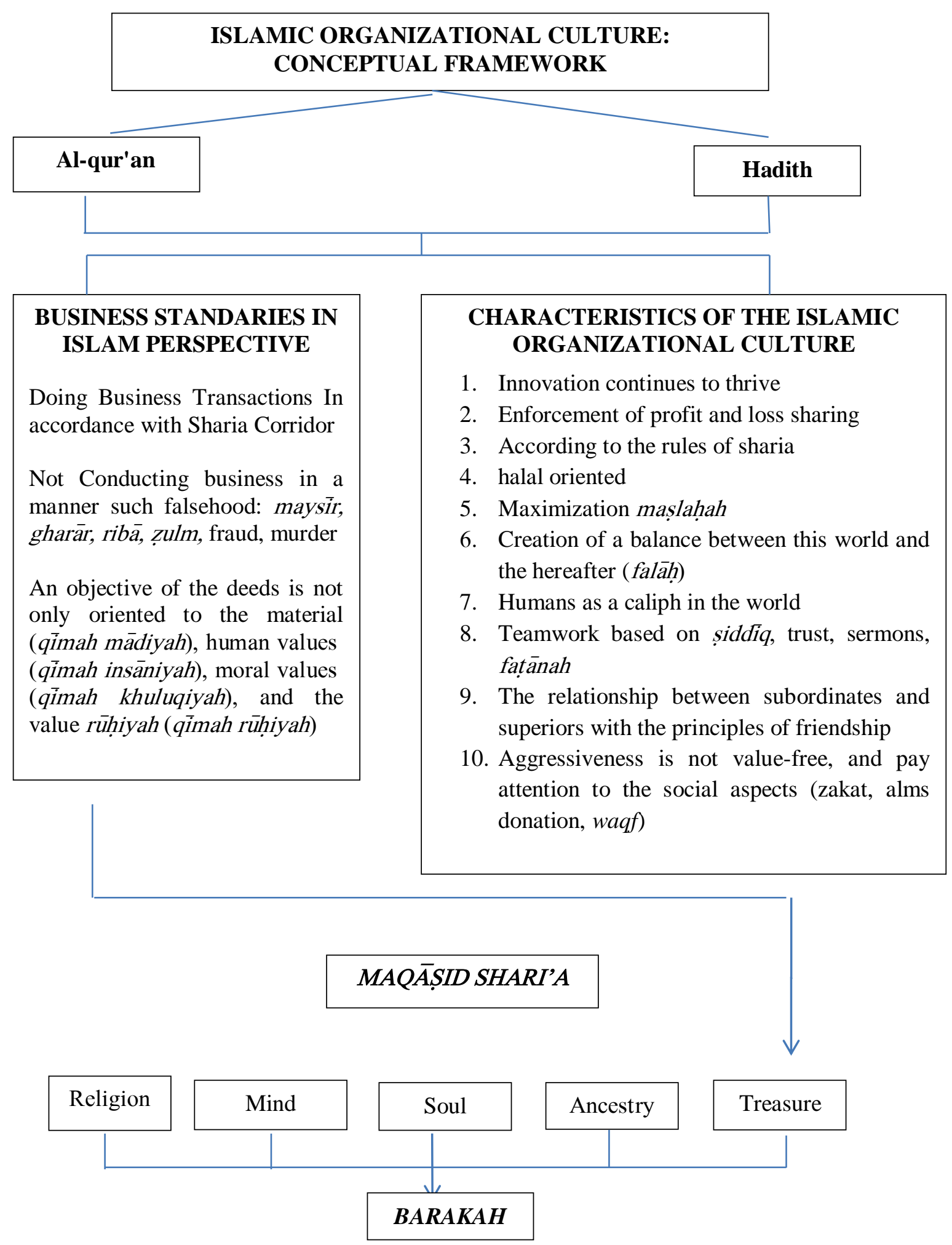


\section{Prior Research Related to Islamic Corporate Culture in Indonesia}

Ratih and the Novel showed that the application of Islamic organizational culture on Rabbani has been implemented consistently and continues to develop. Islamic culture is applied Rabbani became the main base propelling performance across all business functions Rabbani, where the culture is composed of consumer focus, focus and focus quality employees and focus of the organization that includes the core values of innovation Rabbani organization. Rabbani has three principle that has always tried to be applied, namely VSL: Value, with regard to core values, or culture; The system, which is to build the system, procedures, SOP, consequences, and other modules to support the company's performance; Leader, with a good leadership force is expected to mobilize all the elements are there organized. ${ }^{32}$

Byarwari showed that there are two main values that can be used as an Islamic corporate culture for Islamic banks which have been derived from the Quran and the Hadith, which is known to iḥsān and itqān. Ihsān and itqān are two values that cannot be separated, where the value of charity join a company that encourages people to work as a member of the entire company. In the execution of a corporate culture, ihs san will bear the mental attitude of sincere, patient and resigned. This mental attitude encourages disciplined work attitude, meticulous, accurate, timely, consistent, effective, optimal, and appreciate the creative collaboration. All this work attitude ultimately boils down to integrity and professional in their work, which is called itqān. ${ }^{33}$

Furthermore, Kusumawati suggested that the presence of a good Islamic organizational culture (Budai) in Semarang Sultan Agung Islamic University can improve the style of Islamic leadership, work ethic and work behavior Islami Islamic faculty and staff at the Islamic University of Sultan Agung Semarang. The indicators of Islamic organizational culture taken of the fundamental pillars of Islamic Cultural Academy in Sultan Agung Islamic University in Semarang, among others, the following (1) Movement tahärah (environmentally clean and non-smoking), (2) Movement prayers, (3) Movement Islamic dress. ${ }^{34}$

Hidayah and Sutopo suggested that an Islamic organizational culture has an important role to form prestative behavior of individuals in the organization. Organizations that have built their organizational culture of values or principles of Islam could encourage individual behavior expected (achievement) in the organization. ${ }^{35}$

According to Aziz and Shofawati, Islamic organizational culture has a significant effect on Islamic work motivation. This shows that MSME in Magetan has adopted the Islamic organizational culture based on the Quran and the Sunnah of the Prophet Muhammad and the Islamic work culture is applied in organizations that create the motivation for employees. Simultaneously the Islamic leadership and Islamic organizational culture influence on Islamic work motivation. This suggests that the leadership which is based on Islamic law and culture

\footnotetext{
${ }^{32}$ Ratih Purbasari and Nurillah Jamil Achmawati Novel, "Analisis Budaya Organisasi Islami Dalam Mendorong Inovasi Organisasi pada Rabbani Holding Bandung", Jurnal Adbispreneur, Vol. 1, No. 1 (April, 2016), 27-37.

${ }^{33}$ Anis Byarwati, "Creating Islamic Corporate Culture Model for Islamic Banking, Jurnal Ekonomi Dan Bisnis Islam, Vol. 2, No. 2 (Juli-Desember, 2016), 205-218.

${ }^{34}$ Diah Ayu Kusumawati, "Peningkatan Perilaku Kerja Islami, 233-242.

${ }^{35}$ Siti Hidayah and Sutopo, "Peran Budaya Organisasional Islami dalam Membentuk Perilaku Prestatif di dalam Organisasi, Jurnal Ekonomi Manajemen dan Akuntansi, Vol. 21, No. 36 (April, 2014), 1-11.
} 
in the organization can improve employee motivation in the organization so that it can produce optimal performance. ${ }^{36}$

Results of research conducted by Ariyanto showed that first, there is a positive relationship between organizational culture and Islamic spiritual leadership. Second, the Islamic organization's culture and spiritual leadership partially had a significant impact on job satisfaction. Third, the Islamic organizational culture and spiritual leadership simultaneously significant affect on job satisfaction. ${ }^{37}$

Research conducted by Hakim states that Islamic leadership and Islamic organizational culture has an influence on Islamic work motivation and employee performance of PT Bank Muamalat Indonesia Central Java. The indicators of Islamic leadership used are siddiq, trustworthy, tabligh, fatänah. While the Islamic organizational culture indicators used are smile, regards, brotherhood, honesty, help each other, and discipline. ${ }^{38}$

\section{Corporate Culture on Islamic Bank in Indonesia}

1. Bank Muamalat Indonesia

The year 2016 becomes the redefining year for the Corporate Culture of Muamalat to become values that include Islamic, Modern and Professional (IDEAL) summarized as follows: ${ }^{39}$

a. Islamic

Maintaining Integrity in every activity according to Islamic teachings, ethics and rules that apply.

b. Modern

1) Responsive and innovative in providing solutions.

2) Think positive and open to change.

c. Professional

1) Competent and responsible for the duties and obligations.

2) Process-oriented and service Prima.

2. Bank Syariah Mandiri

BSM currently has a platform of cultural programs BSM Corporate Culture ETHIC (Excellence, Teamwork, Humanity, Integrity and Customer Focus) to 5 (five) pillars of culture (Culture of Excellence) is IHSAN, Service \& Sales, Risk \& Compliance, Learning \& Sharing and Performance which becomes the main reference in making BSM cultural program that has been implemented. ${ }^{40}$

\footnotetext{
${ }^{36}$ Rezy Aziz Dan Atina Shofawati, "Pengaruh Kepemimpinan Islami dan Budaya Organisasi Islami terhadap Motivasi Kerja Islami pada UMKM Kulit di Magetan, Jurnal Ekonomi Syariah Teori Dan Terapan, Vol. 1, No. 6 (Juni, 2014), 393-409.

${ }^{37}$ Agus Ariyanto, "Pengaruh Budaya Organisasi Islami dan Kepemimpinan Spiritual terhadap Kepuasan Kerja Karyawan MQ Corporation Bandung, Jurnal Ilmu Manajemen Muhammadiyah Aceh, Vol. 2, No. 1 (2014), 5077.

${ }^{38}$ Abdul Hakim, The Implementation of Islamic Leadership, 77-90.

${ }^{39}$ Bank Muamalat Indonesia, Budaya Perusahaan, Laporan Tahunan Bank Muamalat Indonesia Tahun 2016, 60.

${ }^{40}$ Bank Mandiri Syariah, Pernyataan Mengenai Budaya Perusahaan, Laporan Tahunan Bank Muamalat Indonesia Tahun 2016, 245.
} 
Strengthening Cultural Transformation 2016-2020 corplan done through changes in employee behavior that has a spirit PAS BSM (confidence, enthusiasm and spirit), namely:

a. Confidence:

Have a strong belief in the ability and competence in solving tasks and challenges.

b. Enthusiastic:

Have positive energy and spirit that encourages a proactive attitude and consistency.

c. Spirit:

Have commitment to work and strive to achieve a victory/glory.

3. Bank Mega Syariah ${ }^{41}$

Bank Mega Syariah culture reflected in the cultural value of ISE which the purpose and meaning:

a. Integrity

Acted properly because they believe always in control of his.

b. Synergy

Joining forces to achieve better results.

c. Excellent

Always work wholeheartedly to give their best.

4. BCA Syariah ${ }^{42}$

BCA Syariah values reflected in cultural values TRIP:

a. Teamwork.

b. Responsibility.

c. Integrity.

d. Professionalism.

5. BRI Syariah ${ }^{43}$

a. Professionals: seriousness in performing duties in accordance with the technical and ethical standards having been determined.

b. Enthusiastic: Excitement or encouragement to be active and in-depth on any work activities.

c. Appreciation HR: Placing and recognize employees as the Company's primary capital to execute the optimal efforts since planning, recruitment, development and empowerment of qualified human resources as well as treat it either as individuals or groups based on mutual trust, open, fair and appreciative.

d. Resignation: Optimism begins with prayer and manifested through earnest effort and ends with the sincerity of the results achieved.

e. Integrity: Correspondence between words and deeds in implementing the work ethic, values, policies and rules of the organization consistently so trustworthy also continue to adhere to professional ethics and business, despite the difficult circumstances to do so.

\footnotetext{
${ }^{41}$ Bank Mega Syariah, Budaya Perusahaan, Laporan Tahunan Bank Mega Syariah Tahun 2016, 46.

${ }^{42}$ BCA Syariah, Tata Nilai Perusahaan, Laporan Tahunan BCA Syariah Tahun 2016, 34.

${ }^{43}$ BRI Syariah, Nilai-Nilai Perusahaan, Laporan Tahunan BRI Syariah Tahun 2016, 47.
} 
f. Business-oriented: Be responsive to changes and opportunities, always think and act to generate added value in his work.

g. Customer satisfaction: Having awareness of attitudes and actions aimed at satisfying external and internal customers within the Company.

6. BNI Syariah ${ }^{44}$

All human BNI Syariah also have values that serve as a guide in every behavior, namely Amānah and Jamā'ah.

a. Amanah

1) Honest and keep promises.

2) To be responsible.

3) Eager to produce the best work.

4) Work sincerely and prioritize the intention of worship.

5) Serving exceeds expectations.

b. Jamaah

1) Care and dare to give and receive constructive feedback.

2) Build synergies professionally.

3) Dividing useful knowledge.

4) Understanding the relationship work processes.

5) Strengthen effective leadership.

\section{Hasanah}

Values (Corporate value) BNI Syariah is the main character for the employees and the company so that BNI Syariah can be easily recognized. Values are arranged in a spirit of giving kindness by building value-value, good on any product, service and daily behavior hasanah insan. Insan figure hasanah collectively achieved by implementing pillars-pillars trustful and Jamaat.

\section{Developing the Quality of Islamic Corporate Culture on Islamic Bank in Indonesia}

Islamic banks today continue progressing so massive. The numbers for 1998 has only one Islamic Bank and 76 BPRS, in June 2016 the increase reached 12 Islamic banks, 22 unit of sharia business, and 165 BPRS. Here is the data development of Islamic bank in Indonesia:

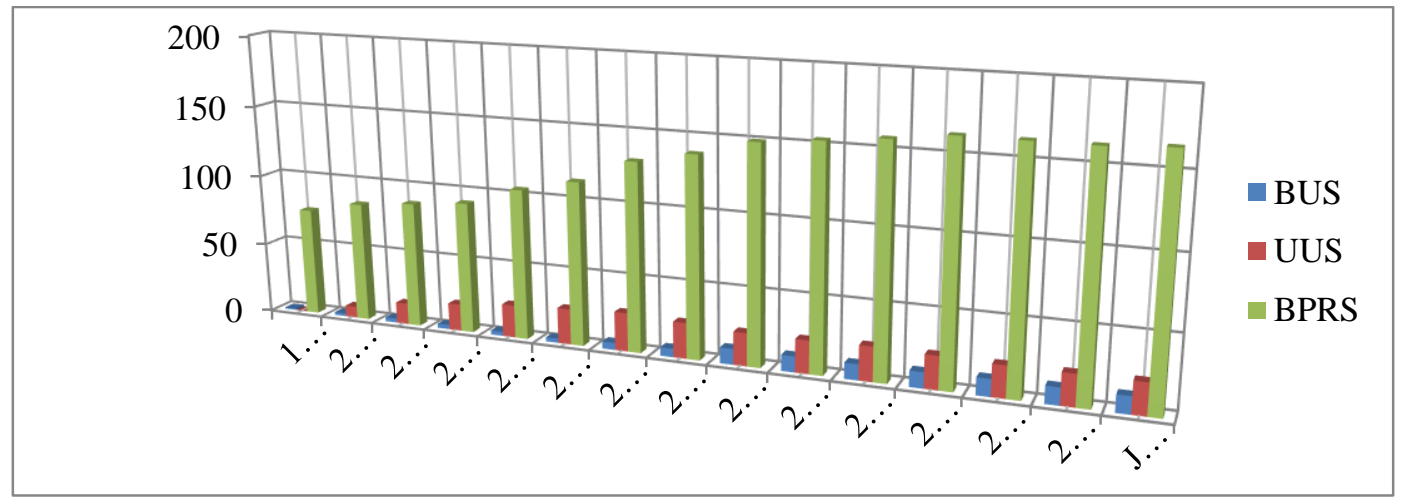

Source: Statistics Islamic Bank Financial Services Authority in June 2016

\footnotetext{
${ }^{44}$ BNI Syariah, Tata Nilai BNI Syariah, Laporan Tahunan BNI Syariah Tahun 2016, 75.
} 
Despite the development and growth of Islamic Bank is currently very high, which products and the market is growing so fast and dinamic. Nevertheless, practice in Islamic Bank today is much different from the theoretical models that promote the practice of profit and loss sharing. ${ }^{45}$ It can be seen from significant deviations in the structure of assets following. ${ }^{46}$

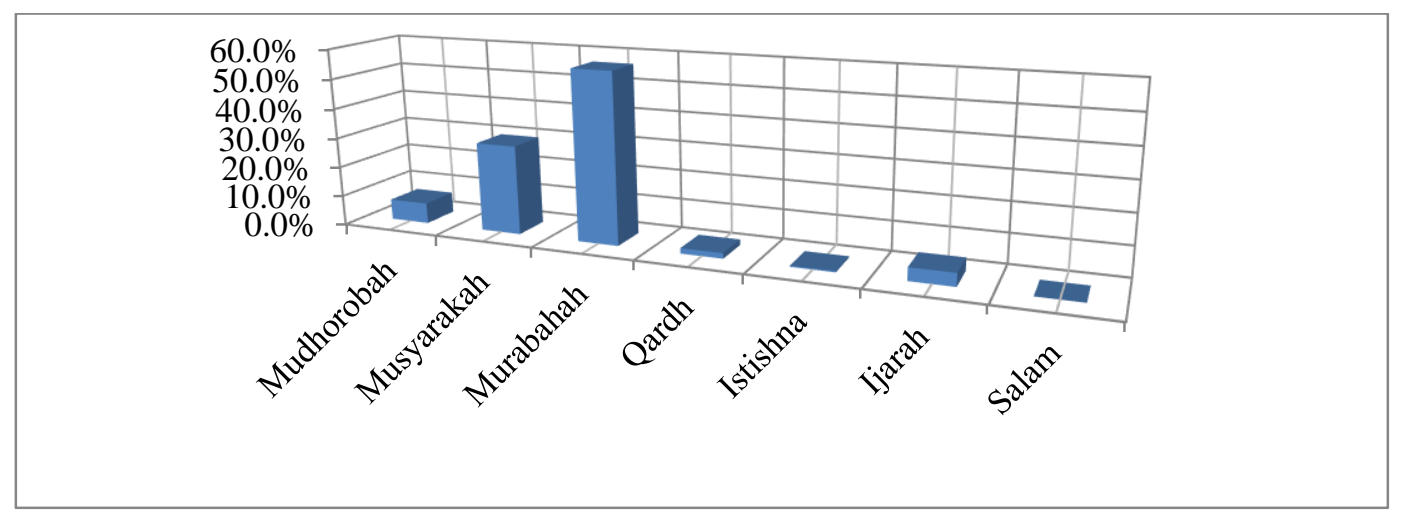

The deviation of Islamic bank practices does not stop there. A similar case was also conducted by Bank Mega Syariah which dominated the distribution of muräbahah accounts receivable of $99.38 \%$ in 2013, and as much as $97.8 \%$ in 2014 and $2015 .{ }^{47}$ In 2013, Bank Syariah Mandiri Bogor exposed cases of fraud by invoking the fictitious loan amount 102 billion rupiah conducted by three employees of Bank Syariah Mandiri Bogor. ${ }^{48}$ In the system, Bank Syariah Mandiri is a bank that has a market capitalization fund's largest Islamic bank in Indonesia, even financial achievements so stunning. Still can commit fraud conducted by superiors managers (top management).

Seeing problematic, we can conclude that, the growth of Islamic bank is so high, only due to the high share of the market muslims in Indonesia, as well as systemic demands by Bank Indonesia in order to convert the commercial bank to commercial Islamic bank. Thus, the Islamic banks are running at this time still in the system, which is still transfixed by the standarization of the Financial Services Authority (FSA), National Sharia Board Fatwa Indonesian Ulama Council (DSN-MUI), and Supervision Sharia Supervisory Board (DPS).

On the basis of the case, if the Islamic bank does not immediately make corrections to the organizational culture of the company well, then there will be a gradual failure. Factors that cause failure include failure of leadership transformation, do not appreciate the external changes that are so fast, the failure of managers in paying attention to employee

\footnotetext{
${ }^{45}$ Zamir Iqbal and Abbas Mirakhor, An Introduction to Islamic Finance Theory and Practice (Singapore: John Wiley \& Sons, 2007), 150.

${ }^{46}$ M. Rusydi, "Syariah Compliance dalam Penerimaan Produk Perbankan Syariah: Aplikasi Theory of Planned Behaviour”, (Disertasi--UIN Sunan Kalijaga Yogyakarta, 2016), 2.

47 Data diolah dari Laporan Tahunan Bank Mega Syariah Tahun 2013. Laporan Tahunan Bank Mega Syariah Tahun 2014. Serta, Laporan Tahunan Bank Mega Syariah Tahun 2015.

48 Viva News, "Kronologi Kasus Kredit Fiktif Rp. 102 M di Bank Syariah Mandiri Bogor", dalam http://nasional.news.viva.co.id/news/read/453908-kronologi-kasus-kredit-fiktif-rp102-m-di-bank-syariahmandiri-bogor diakses tanggal 30 Agustus 2016.
} 
involvement. ${ }^{49}$ Failure indicates that the traditional model does not provide answers to the problems encountered. ${ }^{50}$

Islamic bank is designed to introduce Islamic values in the field of finance and banking. The advantage of Islamic banking is not only determined by the things that are visible (tangible), but also by things that are invisible (intangible), such as the extent to which the values of Islam are implemented and how strong those values incorporated into the corporate culture. Islamic corporate culture for Islamic banks is the soul and personality should be reflected every day and in all activities in the company. In addition, the islamic corporate culture for Islamic banks also creates an identity that distinguishes Islamic banks than conventional banks. ${ }^{51}$

Growth and development of Islamic banks should not only be applied in the system (by the system) but must be accompanied by the application of culture (by culture). By developing a corporate culture of quality in accordance with Islamic principles, the company may provide justice, and did not commit fraud (fraud) are systemic. Rijal, ${ }^{52}$ Hussein, et al ${ }^{53}$ states, that the culture of the organization has affected the growth and development of the organization.

The leader, as the motoric companies have an important role in the realization of Islamic corporate culture. Leaders who are honest (șiddiq), responsibility (amānah), professional (tabligh), and smart (fatänah) can be role models for employees. Thus, the implementation of Islamic leadership style will be able to create an atmosphere of Islamic values-based corporate culture significantly.

The identity of the leader can start in becoming a leader for themselves as word of the Prophet Muhammad.

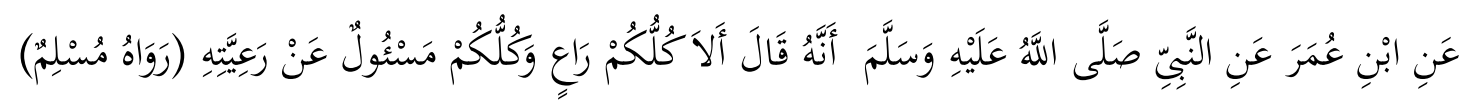

Improving the quality of Islamic values-based corporate culture will influence significantly to the increase in work motivation, job satisfaction, work ethic, prestatif behavior of employees, and employee performance. Based on this, it is important for Islamic bank in Indonesia to develop the quality of corporate culture by using the approach of Islamic values, in order to compete in a competitive (competitive advantage) and develop in a sustainable (sustainable development).

\footnotetext{
${ }^{49}$ Xiongwei Song, "Why Do Change Management Strategies Fail?", Journal of Cambridge Studies, Vol 4. No. 1 (2009), 6-15. See also, Michael Stanleigh, "Effecting Successful Change Management Initiatives", Industrial and Commercial Training, Vol. 40, No. 1 (2008), 34 -37.

${ }^{50}$ Eddie Kikelly, "Creating Leaders for Successful Change Management", Strategic Human Resource Review, Vol. 13, No. 3 (2014), 127-129.

${ }^{51}$ Anis Byarwati, "Creating Islamic Corporate Culture Model For Islamic Banking, Jurnal Ekonomi Dan Bisnis Islam, Vol. 2, No. 2 (Juli-Desember, 2016), 205-218.

${ }^{52}$ Sapna Rijal, "Leadership Style and Organizational Culture In Learning Organization: A Comparative Study", International Journal of Management \& Information Systems, Vol. 20, No. 2 (2016), 11-26.

${ }^{53}$ Norashikin Hussein, dkk.,"Learning Organization Culture, Organizational Performance and Organizational Innovativeness in a Public Institution of Higher Education in Malaysia: A Preliminary Study", Procedia Economics and Finance, Vol. 37 (2016), 512-519.
} 


\section{Conclusion}

1. Growth and development of Islamic banks should not only be applied by system but must be accompanied by the application of culture (by culture). Islamic corporate cultures in Islamic bank in Indonesia have to be evaluated and improved in order to create superior competitiveness (competitive advantage) and sustainable development.

2. The characteristics of Islamic corporate culture are innovation continues to grow and the introduction of profit and loss sharing; Attention in the details as sharia corridor; oriented to halal results, maslahah maximization, and the creation of a balance of advantages and Hereafter (faläh); Human orientation as caliph in the world; team orientation based on siddiq, amānah, tabligh, fatānah and the principle of friendship; Aggressiveness is not value-free, and pay attention to the social aspects (zakat, donation, charity, endowments); Stability in terms of fulfillment of maqāsid sharia, and the creation of a blessing.

3. A major factor in the realization of Islamic corporate culture can be determined by a leader who is running the company. Leaders who are honest (siddiq), responsibility (amānah), professional (tabligh), and smart (fatānah) can be applied by role models for employees. Thus, the application of Islamic leadership style is a major factor in the realization of Islamic corporate culture.

4. Islamic Corporate culture has a major role in increasing employee motivation, employee work ethic, job satisfaction, employee's prestigious behavior and employee performance. Thus, it is important for Islamic banks to develop the quality of corporate culture based on Islamic values.

\section{Daftar Rujukan}

Alnasseri dkk. "Organizational Culture, Leadership Style and Effectiveness: A Case Study of Middle Eastern Construction”. Proceedings 29th Annual ARCOM Conference, England, 2013.

Ariyanto, Agus. "Pengaruh Budaya Organisasi Islami dan Kepemimpinan Spiritual terhadap Kepuasan Kerja Karyawan MQ Corporation Bandung”. Jurnal Ilmu Manajemen Muhammadiyah Aceh. Vol. 2, No. 1, 2014.

Bank Muamalat Indonesia. Budaya Perusahaan. Laporan Tahunan Bank Muamalat Indonesia Tahun 2016.

Bank Mandiri Syariah. Pernyataan Mengenai Budaya Perusahaan. Laporan Tahunan Bank Muamalat Indonesia Tahun 2016.

Bank Mega Syariah. Budaya Perusahaan. Laporan Tahunan Bank Mega Syariah Tahun 2016. . Laporan Tahunan Bank Mega Syariah Tahun 2013. . Laporan Tahunan Bank Mega Syariah Tahun 2014. . Laporan Tahunan Bank Mega Syariah Tahun 2015.

Belak, Jernej. "Organizational Culture in Relation to Enterprise Life Cycle". Kybernetes, Vol. 45, No. 4, 2016.

BCA Syariah. Tata Nilai Perusahaan. Laporan Tahunan BCA Syariah Tahun 2016.

BNI Syariah. Tata Nilai BNI Syariah. Laporan Tahunan BNI Syariah Tahun 2016.

BRI Syariah. Nilai-Nilai Perusahaan. Laporan Tahunan BRI Syariah Tahun 2016.

Byarwati, Anis. "Creating Islamic Corporate Culture Model for Islamic Banking. Jurnal 
Ekonomi Dan Bisnis Islam. Vol. 2, No. 2, Juli-Desember, 2016.

Cengiz, Yilmaz dan Ercan Ergun. "Organizational Culture and Firm Effectiveness: An Examination of Relative Effects of Culture Traits and The Balanced Culture Hypothesis in an Emerging Economy". Journal of World Business. Vol. 43, No. 3, 2008.

Danish, Rizwan Qaiser et.al. "Moderating Role of Organizational Culture Between Knowledge Management and Organizational Effectiveness in Service Sector". World Applied Sciences Journal. Vol. 20, No. 1, 2012.

Edmonds, John. "Managing Successful Change". Industrial and Commercial Training. Vol. 43, No. 6, 2011.

Goh, Phaik Lan. "The Implementation of Total Quality Management In Small and Medium Entreprise". Disertation--University of Sheffield, 2010.

Gómez-Miranda, M. Elena, dkk. "The Impact of Organizational Culture on Competitiveness, Effectiveness and Efficiency in Spanish-Moroccan International Joint Ventures". Personnel Review. Vol. 44, No. 3, 2015.

Guiso, Luigi et.al. "The Value of Corporate Culture". Journal of Financial Economics. Vol. $117,2015$.

Hakim, Lukman. "Budaya Organisasi Islamimi Sebagai Upaya Meningkatkan Kinerja". Iqtishadia. Vol. 9, No. 1, 2016.

Hidayah, Siti dan Sutopo. "Peran Budaya Organisasional Islami dalam Membentuk Perilaku Prestatif di dalam Organisasi”. Jurnal Ekonomi Manajemen dan Akuntansi. Vol. 21, No. 36, 2014.

Hoque, Nazamul et.al. "Organisational Culture: Features And Framework From Islamic Perspective". Journal Humanomics. Vol. 29, No. 3, 2013.

Husni, Muhammad. "Membangun Budaya Organisasi dalam Perspektif Nilai-Nilai Islam. Cendekia: Jurnal Hasil Penelitian dan Pengembangan Pendidikan Islam. Vol. 8, No. 2, 2015.

Hussein, Norashikin dkk. "Learning Organization Culture, Organizational Performance and Organizational Innovativeness in a Public Institution of Higher Education in Malaysia: A Preliminary Study". Procedia Economics and Finance. Vol. 37, 2016.

Iqbal, Zamir dan Abbas Mirakhor. An Introduction to Islamic Finance Theory and Practice. Singapore: John Wiley \& Sons, 2007.

Jørgensen, Hans Henrik et.al. "Stop Improvising Change Management". Strategy \& Leadership. Vol. 37, No. 2, 2009.

Kikelly, Eddie. "Creating Leaders for Successful Change Management". Strategic Human Resource Review. Vol. 13, No. 3, 2014.

Kumar, Sanjiv dkk. "Change Management Skills: Leadership and Strategic Management for Health Professionals". Indian Journal of Community Medicine. Vol. 40, No. 2, 2015.

Kusumawati, Diah Ayu. "Peningkatan Perilaku Kerja Islami Dengan Budaya Organisasi Islami Sebagai Variabel Moderasi". $2^{\text {nd }}$ Conference In Business, Accounting, and Management, Vol. 2, No. 1, 2015.

Kuula, Markku et.al. "Effect of Change: A Longitudinal Study Into The Changing Manufacturing Structures”. Benchmarking: An International Journal. Vol. 21, No. 3, 2014. 
Laforet, Sylvie. "Effects of Organizational Culture on Organizational Innovation Performance In Family Firms". Journal of Small Business and Enterprise Development. Vol. 23, No. 2, 2016.

Naserinajafabady, Razieh et.al. "Effects of Organizational Culture, Structure and Strategy on Organizational Effectiveness by Using Knowledge Management, Case Study: Seven International Transportation Company". International Research Journal of Applied and Basic Sciences. Vol, 7, No. 6, 2013.

News, Viva. "Kronologi Kasus Kredit Fiktif Rp. 102 M di Bank Syariah Mandiri Bogor" dalam http://nasional.news.viva.co.id/news/read/453908-kronologi-kasus-kredit-fiktifrp102-m-di-bank-syariah-mandiri-bogor, diakses tanggal 30 Agustus 2016.

Peronja, Ivan. "Performance Effects of The Business Process Change in Large Enterprises". Management. Vol. 20, No. 1, 2015.

Poerwanto. Budaya Perusahaan. Yogyakarta: Pustaka Pelajar, 2008.

Potnuru, Rama Krishna Gupta and Chandan Kumar Sahoo. "HRD Interventions, Employee Competencies and Organizational Effectiveness: An Empirical Study". European Journal of Training and Development. Vol. 40, No. 5, 2016.

Purbasari, Ratih dan Nurillah Jamil Achmawati Novel. "Analisis Budaya Organisasi Islami dalam Mendorong Inovasi Organisasi pada Rabbani Holding Bandung. Jurnal Adbispreneur. Vol. 1, No. 1, 2016.

Rezy, Aziz dan Atina Shofawati. "Pengaruh Kepemimpinan Islami dan Budaya Organisasi Islami Terhadap Motivasi Kerja Islami Pada UMKM Kulit di Magetan. Jurnal Ekonomi Syariah Teori Dan Terapan. Vol. 1, No. 6, 2014.

Rijal, Sapna. "Leadership Style and Organizational Culture in Learning Organization: A Comparative Study". International Journal of Management \& Information Systems. Vol. 20, No. 2, 2016.

Rivai, Veitzal dkk. Islamic Business And Economics Ethics: Mengacu pada Al-Quran dan Mengikuti Jejak Rasulullah SAW dalam Berbisnis, Keuangan, dan Ekonomi. Jakarta: Bumi Aksara, 2012.

Rusydi, M. "Syariah Compliance dalam Penerimaan Produk Perbankan Syariah: Aplikasi Theory of Planned Behaviour". Disertasi--UIN Sunan Kalijaga Yogyakarta, 2016.

Samuel, Kamugisha. "The Effect Of Change Management in an Organization. Wyno Journal of Management \& Business Studies. Vol. 1, No. 1, 2013.

Song, Xiongwei. "Why Do Change Management Strategies Fail?". Journal of Cambridge Studies. Vol 4. No. 1, 2009.

Stanleigh, Michael. "Effecting Successful Change Management Initiatives". Industrial and Commercial Training. Vol. 40, No. 1, 2008.

Triznova, Miroslava, dkk. "CRM based on Employees and Corporate Culture". Procedia Economics and Finance. Vol. 26, 2015.

Tojari, Farshad, et.al. "Structural Equation Modeling Analysis of Effects of Leadership Styles and Organizational Culture On Effectiveness In Sport Organizations". African Journal of Business Management. Vol. 5, No. 21, 2011.

Uha, Nawawi Ismail. Budaya Organisasi Kepemimpinan dan Kinerja: Proses Terbentuk, Tumbuh Kembang, Dinamika, dan Kinerja Organisasi, cet. ke-2. Jakarta: Prenamedia 
Group, 2015.

J E S Volume 3, Nomor 1, Maret 2018 